\title{
Determination of the Potential of Pistia Stratiotes L. in Removing Nickel from the Environment by Utilizing its Rhizofiltration Capacity
}

\section{Zeliha Leblebici ${ }^{1}$}

https://orcid.org/0000-0002-6127-3809

\section{Esra Dalmiş²}

https://orcid.org/0000-0003-4873-8437

\section{Enver Ersoy Andeden ${ }^{1}$}

https://orcid.org/0000-0001-5774-8990

\begin{abstract}
${ }^{1}$ Nevsehir Haci Bektas Veli Universitesi, Science and Art Faculty, Department of Molecular biology and genetics, Nevsehir, TURKEY; ${ }^{2}$ Nevsehir Haci Bektas Veli Universitesi, Graduate School of Natural and Applied Sciences, Department of Biology, Nevsehir, TURKEY;
\end{abstract}

Received: 2018.09.18; Accepted: 2019.07.08.

*Correspondence: zleblebici@nevsehir.edu.tr Tel.: (+90)0384 2281000/13113

\section{HIGHLIGHTS}

- Pistia stratiotes as an effective Ni accumulator

- Rhizofiltration capacity of Pistia stratiotes hight

- Biological response of Pistia stratiotes sensitive

- Physiological responses of the plant to the heavy metal stress very successufull

Abstract: The aim of this study is to explain the biological response and rhizofiltration capacity of Pistia stratiotes, which is an aquatic macrophyte, in alleviating heavy metal stress. In our study, Pistia species were exposed to Nickel (Ni) at different concentrations over seven days. The potential of the aquatic macrophytes in accumulating heavy metals in the water and in removing them from the environment was evaluated by determining the bio-concentration factors (BCF). Selected biological parameters in the leaves of Pistia stratiotes, including metal accumulation, photosynthetic pigment amount, lipid peroxidation activity, and growth rates were measured at the end of the seven-day period. The highest amount of $\mathrm{Ni}$ accumulation in $\mathrm{P}$. stratiotes occurred at a concentration of $20 \mathrm{mg} \mathrm{l}^{-1}$. The amount of chlorophyll a (chl a) in P. stratiotes reached a value of $0.087 \mathrm{mg} \mathrm{g}^{-1}$ at the Ni concentration of $20 \mathrm{mg} \mathrm{l}^{-1}$. The relative growth rate (RGR) of $P$. stratiotes showed a negative correlation with the increases in the concentration levels of the metal. Malondialdehyde (MDA) levels increased to $8.214 \mathrm{nmol} / \mathrm{g}$ at the concentration of $20 \mathrm{mg} \mathrm{l}^{-1}$, depending on $\mathrm{Ni}$ concentration and time. In our study, the use of $P$. stratiotes has been determined to be an appropriate plant as an effective $\mathrm{Ni}$ accumulator to be utilized with the purpose of rhizofiltration. 
Keywords: Heavy metal; Bioconcentration factor; Pistia stratiotes; Rhizofiltration.

\section{INTRODUCTION}

The environmental conditions have reached a critical level in the world generally due to the rapid development of industrial activities. Environmental pollution due to the toxic metals has been on the rise since the industrial revolution, leading to serious ecological problems $[1,2]$. Several studies were conducted over the last two decades on macrophytes removing the heavy metals from the polluted water [3-5]. These macrophytes include the water ferns (Salvinia molesta, Salvinia auriculata, Salvinia minima), water lettuce (Pistia stratiotes), water hyacinth (Eichhornia azurea, Eichhornia diversifolia, Eichhornia paniculata), and duckweed (Lemna minor) [3,6].

There are several chemical methods available to remove heavy metals from the polluted areas, including electrolysis, reverse osmosis, and adsorption. However, these processes are expensive when they are used for large volumes of water. Therefore, phytoremediation is preferred because of its high efficiency and relatively lower cost. Despite various advantages of the phytoremediation method, not so many species have been studied so far and the appropriate species have not been fully identified, yet $[7,8]$.

The ideal plants to be used for remediation of the areas polluted by heavy metals must have relatively larger root systems that can grow rapidly, has a large biomass, and can uptake and accumulate the pollutants. Therefore, the plants to be used for the remediation of the water polluted by the heavy metals need to be carefully selected.

The principle aim of our study is to determine the rhizofiltration capacity of the Pistia stratiotes plant, to determine the amount of $\mathrm{Ni}$ accumulated in the plant, and to examine the physiological responses of the plant to the heavy metal stress.

\section{MATERIAL AND METHODS}

\section{Sample Material and Preparation for the Experiment Stage}

Pistia stratiotes is a freely floating water plant from the monocotyledon clade and it belongs to the family of Araceae. Its rosette-leaves are flossy and thick, slightly lighter green in color. The plant spreads densely in the shallow areas of rivers, lakes, and marshes. They can also be grown in open-top aquariums and in garden ponds. Pistia is a plant which does not have high-level requirements and it can grow easily even in moderate light and can generally reach larger sizes under bright light. The optimum growth temperature of the Pistia plant is between $22-30^{\circ} \mathrm{C}$. The plant can grow up to $5-6 \mathrm{~cm}$ in diameter in the aquarium conditions while, in nature, it can achieve diameters of up to $20 \mathrm{~cm}$ [9].

Pistia stratiotes plant was brought from Adana and raised in the culture medium in the laboratory. After taking the plants out of the culture medium and washing them using distilled water, they were placed in the plant growth cabinet providing photoperiodic lighting, that is 16 hours of light and 8 hours of dark, at $23^{\circ} \mathrm{C}$ temperature and at a humidity level of $70 \%$. Nickel chloride $\left(\mathrm{NiCl}_{2} 6 \mathrm{H}_{2} \mathrm{O}\right)$ was used to expose the plants to a heavy metal. The plants were kept in $400 \mathrm{~mL}$ beakers in the growth cabinet and $\mathrm{Ni}$ was applied to the plants at different concentrations (1-5-10-20 $\mathrm{mg} \mathrm{l}^{-1}$ ) with $10 \%$ Hoagland solution over duration of seven days 
[4]. A control group without heavy metal exposure was used for each test group during the study and each trial was repeated three times.

\section{Determining the Levels of Nickel}

At the end of the period of exposure to the heavy metal, the plants were taken out from the growth cabinet. They were washed using double-distilled water and dried at $80^{\circ} \mathrm{C}$. Samples weighing $0.5 \mathrm{~g}$ were taken and dissolved in acid in a microwave device using $10 \mathrm{ml}$ of $\mathrm{HNO}_{3}$. After this dissolving procedure, the samples were immersed in double-distilled water to have a volume of $10 \mathrm{ml}$ and then the amount of $\mathrm{Ni}$ was determined with inductively coupled plasma mass spectroscopy (ICP-MS). Peach leaf (SRM-1547 NIST) was used as a reference material for the analytical procedures performed. While the standard value for $\mathrm{Ni}$ was defined to be $0.04 \pm 0.01 \mathrm{~g} \mathrm{I}^{-1}$ for SRM-1547, the concentration of Ni was found out to be $0.03 \pm 0.01 \mathrm{~g} \mathrm{I}^{-1}$ using ICP-MS. Tests were repeated three times for each sample and results were recorded. All the chemicals used in this study conformed to the standards of analytical purity (Merck, Darmstadt, Germany).

Bioconcentration factor (BCF) was calculated as follows [10].

$\mathrm{BCF}=$ The amount of $\mathrm{Ni}$ in the plant biomass $\left(\mathrm{mg} \mathrm{kg}^{-1}\right) /$ the amount of $\mathrm{Ni}$ in the solution $\left(\mathrm{mg} \mathrm{l}^{-1}\right)$

\section{Determining the Relative Growth Rate (RGR) and the Quantity of Photosynthetic Pigments}

To determine the relative growth rate, the harvested samples were placed on a blotting paper and left there for the water to be drained over a period of five minutes. Then, they were desiccated at $80^{\circ} \mathrm{C}$ over a period of 24 hours. After weighing the samples, the relative growth rates were calculated using the equation below.

Relative Growth Rate (RGR) calculation using Hunt's equation:

$\mathrm{R}=\ln \mathrm{W}_{2}-\ln \mathrm{W}_{1} \mathrm{~T}_{2}-\mathrm{T}_{1}$

R: Relative Growth Rate (RGR) $\left(g^{-1} \mathrm{~d}^{-1}\right) ; \mathrm{W}_{1}$ and $\mathrm{W}_{2}$ : initial and final dry weights; $\mathrm{T}_{2}-\mathrm{T}_{1}$ : the time of the start and end of the experiment [11].

The fresh weight was used to determine the amounts of the photosynthetic pigments. After applying the procedures, a $100 \mathrm{mg}$ of plant sample was taken and immersed in $80 \%$ acetone to make a volume of $10 \mathrm{ml}$. The sample was then centrifuged over a period of 10 minutes at $10,000 \mathrm{x} \mathrm{g}$. The quantities of the photosynthetic pigments (chlorophyll a and carotenoids) were determined at 450,645 , and $663 \mathrm{~nm}$ using spectrophotometer [12]. 


\section{Determining the Rhizofiltration Potential (RP) of the Plant}

The rhizofiltration potential (RP) $\left(\mathrm{mg}_{\text {heavy metal }} \mathrm{m}^{-2}\right.$ year $\left.{ }^{-2}\right)$ of the harvested plants represents the ratio of the total amount of heavy metal, to which the plant was exposed, to the amount of heavy metal found out at the end of the experiment. RP was calculated using the below modified formula by Neugschwandtner et al. [13].

$R P=\frac{\left\{\mathrm{C}_{\text {leaves }} * \mathrm{M}_{\text {leaves }}+\mathrm{C}_{\text {roots }} * \mathrm{M}_{\text {roots }}\right\}_{\star}}{\mathrm{M}_{\text {total }} \mathrm{M}_{\text {total }}} \mathrm{M}_{\text {plant }}$

Fonkou et al. [14] defined that $M_{\text {leaves }}$ denoted dry biomass yield of the leaves ( $g$ ); $M_{\text {total }}$ denoted total dry biomass yield ( $g$ ) (leaves and the roots); $\mathrm{C}_{\text {leaves }}$ denoted the amount of

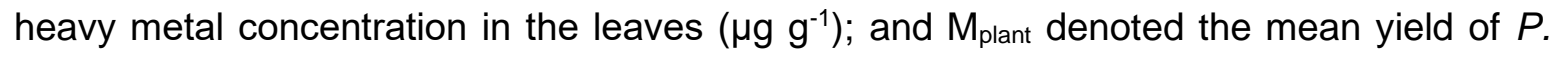
straiotes (g DW $\mathrm{m}^{-2}$ year $\left.^{-1}\right)$.

\section{Measuring Lipid Peroxidation}

After the experiment, a $500 \mathrm{mg}$ plant sample was taken and homogenized in $3 \mathrm{ml}$ of $20 \%$ TCA (w/v) in $0.5 \%$ TBA. The homogenate was incubated at $95^{\circ} \mathrm{C}$ over a period of 30 minutes and then, the reaction was stopped using ice. The samples were centrifuged at $10,000 \times \mathrm{g}$ for 10 minutes and the absorbance of the resulting supernatant was measured at $532 \mathrm{~nm}$ and $600 \mathrm{~nm}$ with a spectrophotometer. The amount of MDA was calculated using the values obtained at $532 \mathrm{~nm}$ and $600 \mathrm{~nm}$ [15].

\section{Statistical Analysis}

The obtained data were expressed as standard errors (SE) and mean values. One-way analysis of variance (ANOVA) was used to confirm the validity of the data and the results. The Duncan test was used to determine the significant difference between the procedures. Statistical significance was accepted to be $p \leq 0.05$. All statistical analyzes were performed using SPSS 17.0 software package.

\section{RESULTS AND DISCUSSION}

\section{Bioaccumulation and toxicity of nickel}

In our study, the accumulation of nickel in plant leaves was determined. On the 7th day of the heavy metal exposure, the maximum $\mathrm{Ni}$ accumulation $\left(1820.18 \mu \mathrm{g} \mathrm{g}^{-1}\right)$ was observed in $P$. stratiotes samples exposed to $\mathrm{Ni}$ at a concentration of $20 \mathrm{mg} \mathrm{l}^{-1}$, as shown in Figure 1. The $\mathrm{Ni}$ accumulation on the leaves of $P$. stratiotes and the Ni concentrations applied to the plant were positively correlated with each other $(R=0.919, P \leq 0.01)$. It is demonstrated clearly in Figure 1 that the bioaccumulation of metals in the plants increases not only by time but also with the increasing levels of metal concentration, which they were exposed to. In our study, a 
high level of heavy metal accumulation was detected in the plant over the period of seven days.

The accumulation potential of aquatic plants in removing heavy metals from the environment has been examined in several studies using different methods [16-19]. The researchers have proved that the aquatic plants are able to accumulate various heavy metals at high concentrations. As shown in Figure 1,P. stratiotes showed higher rates of accumulation of $\mathrm{Ni}$, depending on the increases in concentrations exposed, over the period of seven days in our study.

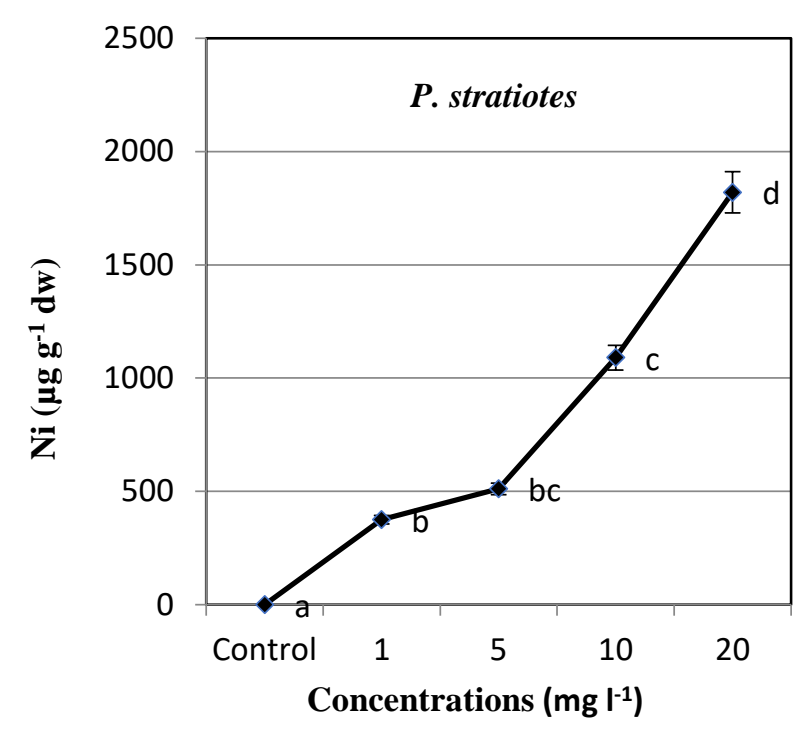

Figure 1. Ni accumulation by $P$. stratiotes at the end of the seven days of exposure to various concentrations of $\mathrm{Ni}\left(1-5-10-20 \mathrm{mg} \mathrm{l}^{-1}\right)$. All values are presented with the standard deviation as \pm SD. ANOVA significance level was accepted to be $p \leq 0.05$.

The initial metal concentration, to which the plant is exposed, is a parameter required to determine the metal concentration that accumulates during the whole period of exposure [20]. Zayed et al. [21] report that only plants with more than 1,000 BCFs should be considered as good accumulators. Odjegba and Fasadi [19] discovered that $P$. stratiotes was a very efficient copper accumulator. As shown in Figure 2, our study results confirm that $P$. stratiotes is is a good accumulator for $\mathrm{Ni}$ and that it has a high potential for remediating water contaminated with $\mathrm{Ni}$. 


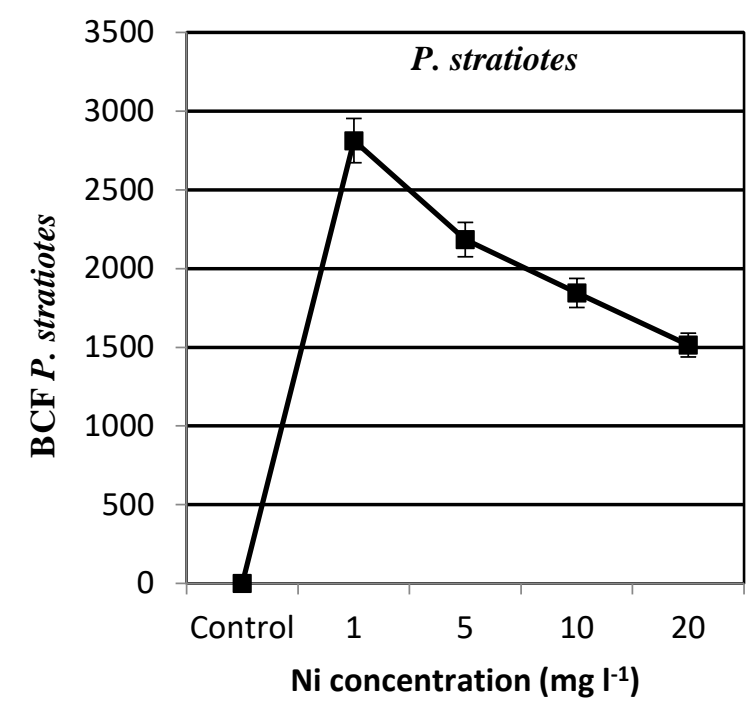

Figure 2. The levels of the bioconcentration factor (BCF) of $P$. stratiotes exposed to Ni over a period of seven days. The vertical bars indicate $S D, n=3$.

The effect of Ni exposure on the growth rate of $\boldsymbol{P}$. stratiotes and on the amount of photosynthetic pigments

With the increased concentrations of the heavy metal, to which the plant was exposed, the relative growth rate of the plant decreased (Figure 3) and the accumulated heavy metal caused a darker coloring on the leaves. As shown in Figure 3, at the end of the 7th day, the highest decrease in RGR of $P$. stratiotes was observed with the samples exposed to a $\mathrm{Ni}$ concentration of $20 \mathrm{mg} \mathrm{l}^{-1}$. A significant effect on the growth parameters was observed, like the chlorosis of the leaves, in the plants exposed to Ni concentrations of 10 and $20 \mathrm{mg} \mathrm{l}^{-1}$. A significant negative correlation was determined between the RGR values and the concentrations of $\mathrm{Ni}$ applied to the $P$. stratiotes $(\mathrm{R}=-0.898, \mathrm{p} \leq 0.01)$. 


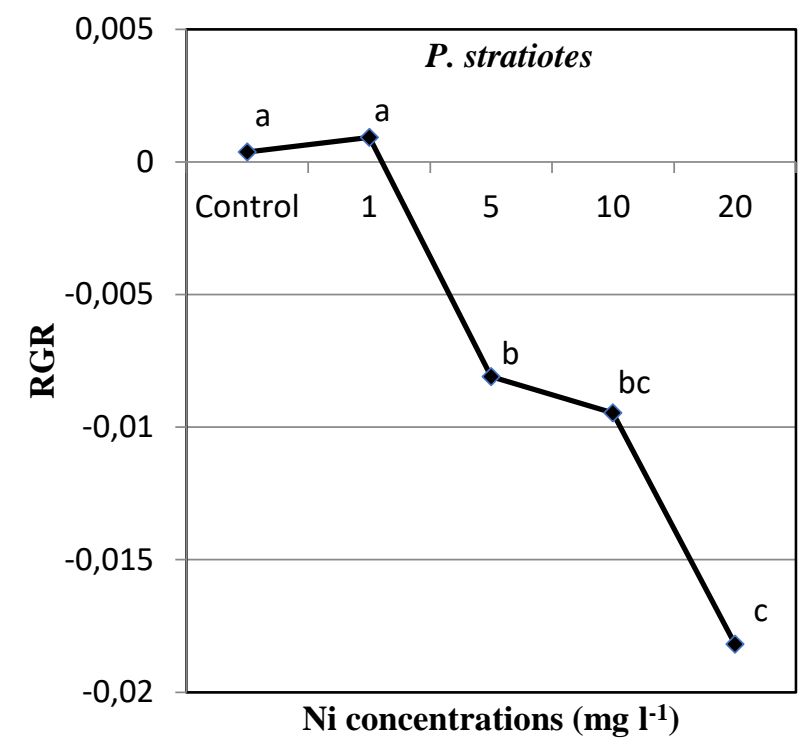

Figure 3. The relative growth rates at the end of the period of $\mathrm{Ni}$ application to the $P$. stratiotes. All values are presented with the standard deviation as \pm SD. ANOVA significance level was accepted to be $p \leq 0.05$.

Usually, the first and the most obvious response of the plants to heavy metal stress is the change in the growth rate. This present study has shown that the lower doses of $\mathrm{Ni}\left(1 \mathrm{mgl}^{-1}\right)$, which is a trace element, have increased the growth rate of $P$. stratiotes slightly. However, the higher doses of $\mathrm{Ni}$ have led to adverse effects on the growth of the plant. Ugya et al. [16] have similarly reported that the heavy metals, which are the trace elements, accelerate the growth at relatively lower doses, but they cause toxic effects at higher doses.

It is known that the toxic metals produce reactive oxygen species (ROS) that destroy the cell walls and cell membranes of the plants under stress depending on the concentration of exposure. The RGR values may be reduced at higher concentrations of exposure due to the effects of ROS [22]. Our study results are fully supportive of these findings.

As shown in Figure 4, the amount of chlorophyll in $P$. stratiotes showed a negative correlation with the applied concentration levels of $\mathrm{Ni}$. When $P$. stratiotes leaves were exposed to $1 \mathrm{mg} \mathrm{l}^{-1}$ or higher concentrations of $\mathrm{Ni}$, a reduction in the amount of chlorophyll pigment was observed. Figure 4 shows that, at the end of the 7th day, the lowest amount of chlorophyll pigment was found out to be $0.79 \mathrm{mg} \mathrm{g}^{-1}$ in the samples exposed to a concentration of $20 \mathrm{mg} \mathrm{I}^{-1}$, compared to the control sample $\left(1.52 \mathrm{mg} \mathrm{g}^{-1}\right) \quad(R=-0.908$, $\mathrm{p} \leq 0.01)$.

Figure 4 also shows that the carotenoid levels decreased in the plant depending on the $\mathrm{Ni}$ concentrations exposed to and by time. The minimum level of carotenoid was found out to be $0.59 \mathrm{mg} \mathrm{g}^{-1}$ in the leaves of $P$. stratiotes in the samples exposed to a Ni concentration of $20 \mathrm{mg} \mathrm{l}^{-1}(\mathrm{R}=-0.912, \mathrm{p} \leq 0.01)$. As shown in Figure 4, the photosynthetic pigment levels in the plants exposed to $\mathrm{Ni}$ were determined to be lower compared to the control sample for all concentrations of exposure. 


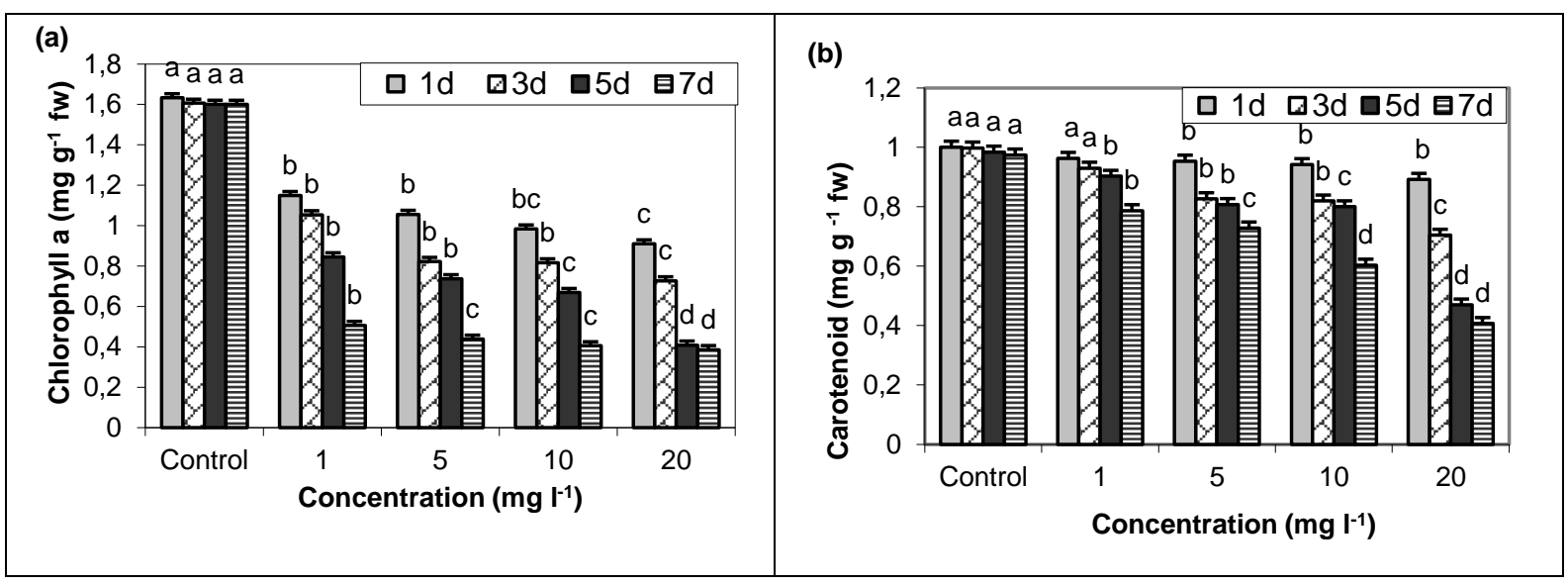

Figure 4. The effects of $\mathrm{Ni}$ on chlorophyll a (a) and carotenoid (b) levels in the P. stratiotes plant. All values are presented with the standard deviation as \pm SD. ANOVA significance level was accepted to be $p \leq 0.05$.

Vesely et al. [18] detected a decrease in the amount of the photosynthetic pigment in the leaves of $P$. stratiotes. Our study results support this finding as it has been found out that the chlorophyll content of $P$. stratiotes decreases by the higher concentrations of exposure.

The photosynthetic pigments (chlorophyll and carotenoids) in green plants are important components of the photosynthesis system. A significant change in the amount of pigments can lead to the adverse consequences on the entire metabolism of the plant, through the degradation of membrane lipids and the reactive oxygen species, decreases in the intake of nutrients (such as $\mathrm{Mn}, \mathrm{Cu}, \mathrm{Fe}$, and $\mathrm{P}$ ), or degradation of chlorophyll [23].

\section{The rhizofiltration capacity of $\boldsymbol{P}$. stratiotes}

The rhizofiltration potential $(\mathrm{RP})$ is an indicator of the actual uptake of the heavy metal from the environment. The RP values calculated for $P$. stratiotes after heavy metal exposure in the experiment are presented in Table 1. $P$. stratiotes's rhizofiltration potential showed an increase as the $\mathrm{Ni}$ concentrations increased over the entire experiment. At the end of the experiment, the RP of the plant was determined to be $512 \mathrm{mg} \mathrm{Ni} \mathrm{m}^{-2}$ year $^{-1}$ at the lowest level of $\mathrm{Ni}$ exposure. At the $\mathrm{Ni}$ exposure level of $5 \mathrm{mg} \mathrm{L}^{-1}$, the RP was $834 \mathrm{mg} \mathrm{Ni} \mathrm{m}^{-2}$ year $^{-1}$. At the end of the experiment, the RP was observed to be $1274 \mathrm{mg} \mathrm{Ni} \mathrm{m}^{-2} \mathrm{yll}^{-1}$ at a Ni exposure level of $10 \mathrm{mg} \mathrm{L}^{-1}$ and it was $6210 \mathrm{mg} \mathrm{Ni} \mathrm{m}^{-2}$ year $\mathrm{r}^{-1}$ at a Ni exposure level of $20 \mathrm{mg} \mathrm{L}^{-1}$. Vesely et al. [18] found out that the rhizofiltration potential of the plant, exposed to $\mathrm{Pb}$, continued to increase until the fourth day, and then it decreased. The results of our study, using $\mathrm{Ni}$ exposure, support these findings. 
Table 1. The rhizofiltration potential (RP) of the $P$. stratiotes plant, $\mathrm{mg} \mathrm{HM} \mathrm{m}^{-2}$ year ${ }^{-1}$

\begin{tabular}{|c|c|c|c|c|c|}
\hline \multicolumn{6}{|c|}{$\mathbf{N i}$} \\
\hline & Control & $1 \mathrm{mg} \mathrm{L}^{-1}$ & $5 \mathrm{mg} \mathrm{L}^{-1}$ & $10 \mathrm{mg} \mathrm{L}^{-1}$ & $20 \mathrm{mg} \mathrm{L}^{-1}$ \\
\hline 1.day & $2.1 \pm 0.1$ & $312 \pm 11.4$ & $841 \pm 21.4$ & $1045 \pm 31.4$ & $5471 \pm 34.1$ \\
\hline 3.day & $7.5 \pm 0.8$ & $425 \pm 21.8$ & $956 \pm 24.8$ & $2104 \pm 48.5$ & $8241 \pm 45.7$ \\
\hline 5.day & $11 \pm 1.2$ & $841 \pm 32.7$ & $1245 \pm 32.1$ & $4532 \pm 51.3$ & $7415 \pm 48.6$ \\
\hline 8.day & $18 \pm 2.4$ & $1124 \pm 41.7$ & $2415 \pm 42.1$ & $8241 \pm 62.4$ & $6257 \pm 54.7$ \\
\hline
\end{tabular}

\section{Effects of nickel on MDA levels}

Figure 5 shows that the levels of MDA in the $P$. stratiotes plant are positively correlated with the levels of exposure to $\mathrm{Ni}$. Although the level of MDA was not significantly different at the $\mathrm{Ni}$ exposure level of $1 \mathrm{mg} \mathrm{l}^{-1}$, compared to the control sample; the MDA levels proportionally increased as the concentrations of $\mathrm{Ni}$ applied to the plant increased. Moreover, as shown in Figure 5, the MDA content at the concentration level of $20 \mathrm{mg} \mathrm{l}^{-1}$ was significantly different from that of the control sample $(p \leq 0.05)$. Figure 5 shows that the levels of MDA increased both by time and with the increased $\mathrm{Ni}$ concentrations at the end of the seven-day period, reaching a maximum level of $8.214 \mathrm{nmol} / \mathrm{g}$ with exposure to a concentration of $20 \mathrm{mg} \mathrm{l}^{-1}$ $(R=0.729, p \leq 0.01)$.

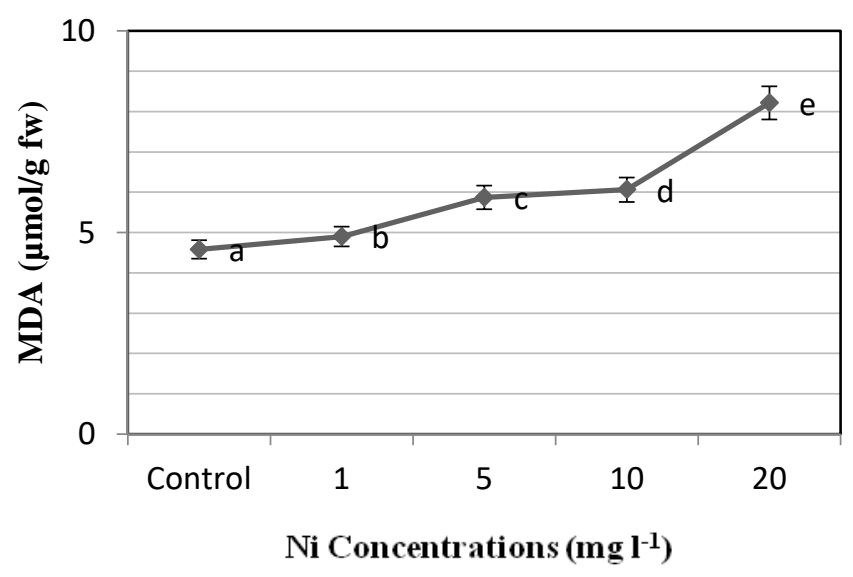

Figure 5. The effects of Ni on lipid peroxidation in $P$ stratiotes. All values are presented with the standard deviation as “ \pm SD". ANOVA significance level was accepted to be $p \leq 0.05$.

The MDA content suggests information on the antioxidant defense mechanism of a given plant. In the literature, it is reported that the plants containing high levels of MDA are under severe stress [24]. With the increases in the levels of heavy metal accumulation; the duration of exposure increases, the activities of the heavy metal enzymes are changed, the membrane permeability is affected, and ion leaks occur; damaging the plant [25]. This study supports the findings in the literature which states that the increases in the concentration and duration of exposure cause increased levels of MDA. 


\section{CONCLUSION}

To conclude,

- P. stratiotes showed an effective accumulation potential, especially with exposure to $\mathrm{Ni}$ at high concentrations.

- Water, the elixir of life existing in our cells, is very important as a universal solvent that carries nutrients and waste matter. In the recent years, the water pollution has become a major problem. The spread of heavy metals such as $\mathrm{Ni}$ in the environment increases the degradation of living and non-living organisms.

- The phytoremediation technology aims to alleviate the pollution via the uptake of the heavy metals by plants. This technology has remarkable advantageous aspects compared to the conventional methods currently in use. To be successful with this method, one of the most important requirements is to select the appropriate plants, which accumulate the metals. For this reason, the research on the phytoremediation capacity of the plants is a critical job in order to solve this environmental problem.

- $\quad P$. stratiotesis is an important plant in the remediation of domestic and industrial wastewater and in the restoration of the mine sites, which are no longer exploited.

- P. stratiotes shows most of the characteristics of the ideal plant species performing phytoremediation using their roots (rhizofiltration).

- The results of our study reveal that $P$. stratiotes plant accumulates $\mathrm{Ni}$ in high quantities and has a high rhizofiltration capacity.

Funding: This research received no external funding

\section{Acknowledgements}

This study was supported by Nevsehir Hacı Bektaş Veli University Research Fund. Project number: NEÜLÜP15F8.

Conflicts of Interest: The authors declare no conflict of interest.

\section{REFERENCES}

1. Leblebici Z, Kar M. Accumulation of Heavy Metals in Vegetables Irrigated with Different Water Sources and Their Daily Intake in Nevsehir. J Agr Sci and Tech. 2018; 20: 401-415.

2. Leblebici Z, Kar M, Yalçın V. Comparative Study of $\mathrm{Cd}, \mathrm{Pb}$, and Ni removal potential by Salvinia natans (L.) All. and Lemna minor L.: Interactions with Growth Parameters. Rom Biotechnol Lett. 2018; 23: 13235-13248.

3. Leblebici Z, Aksoy A, Duman F. Influence of nutrient addition on growth and accumulation of cadmium and copper in Lemna gibba. Chem Speciat Bioavailab. 2010; 22: 157-164.

4. Leblebici Z, Aksoy A. Growth and heavy metal accumulation capacity of Lemna minor and Spirodela polyrhiza (Lemnaceae): Interactions with nutrient enrichment. Water Air Soil Pollut. 2011; 214: 175-184. 
5. Leblebici Z, Aksoy A, Duman F. Influence of salinity on the growth and heavy metal accumulation capacity of Spirodela polyrrhiza (Lemnaceae). Turkish J Biol. 2011; 35: 215-220.

6. Deng $\mathrm{H}$, Ye ZH, Wong MH. Accumulation of lead, zinc, copper and cadmium by 12 wetland plants species thriving in metal contaminated sites in China. Environ Pollut. 2004; 132: 29-40.

7. Hume NP, Fleming MS, Horne AJ. Denitrification Potential and Carbon Quality of Four Aquatic Plants in Wetland Microcosms. Soil Sci Soc Am J. 2002; 66:1706-1712.

8. Duman F, Leblebici Z, Aksoy A. Growth and bioaccumulation characteristics of watercress (Nasturtium officinale R. BR.) exposed to cadmium, cobalt and chromium. Chem Speciat Bioavailab. 2009; 21: 257-265.

9. Schmitz DC, Schardt JD, Leslie AG, Dray FA, Osborne JA, Nelson BV. The ecological impact and management history of three invasive alien aquatic plants in Florida McKnight, B.N. eds. Biological Pollution-the Control and Impact of Invasive Exotic Species. Indiana Acad Sci. 1993; 261.

10. Rahmani GNH, Sternberg SPK. Bioremoval of lead from water using Lemna minor, Bioresour Technol. 1999; 70: 225-230.

11. Hunt R. Plant growth analysis. Studies in biology, Edward Arnold Ltd.: London; 1978.

12. Witham FH, Blaydes DF, Devlin RM. Experiments in plant physiology, New York; 1973.

13. Neugschwandtner RW, Tlustoš $P$, Komárek M, Száková J. Phytoextraction of $\mathrm{Pb}$ and Cd from a contaminated agricultural soil using different EDTA application regimes: Laboratory versus field scale measures of efficiency. Geoderma. 2008; 144: 446-454.

14. Fonkou T, Agendia P, Kengne I, Akoa A, Nya J. Potentials of water lettuce (Pistia stratiotes) in domestic sewage treatment with macrophytic lagoon systems in Cameroon. Proc Int Symposium Environ Pollut Control Waste Manage. Tunis, 2002. 709-714.

15. Heath RL, Packer L. Photoperoxidation in isolated chloroplasts. I. Kinetics and stoichiometry of fatty acid peroxidation. Arch Biochem Biophys. 1968; 125: 189-198.

16. Ugya A, Yunusa T, Sabiu I, Salisu MT. The Use of Pistia stratiotes To Remove Some Heavy Metals From Romi Stream: A Case Study Of Kaduna Refinery And Petrochemical Company Polluted Stream. IOSR J Environ Sci Toxicol Food Technol. 2015; 9: 48-51.

17. Nurhayati P, Sapta A, Siti K, lqbal RF. Water Lettuce (Pistia stratiotes, L.) Potency as One of Eco-friendly Phytoextraction Absorbers of Zinc Heavy Metal to Solve Industrial Waste Problem in Indonesia. IPCBEE. 2012; 41: 151-156.

18. Vesely T, Pavel T, Jirina S. The Use of Water Lettuce (Pistia Stratiotes L.) for Rhizofiltration of a Highly Polluted Solution by Cadmium and Lead. Int $J$ Phytoremediation. 2011; 13:859-872.

19. Odjegba VJ, Fasidi IO. Accumulation of Trace Elements by Pistia stratiotes: Implications for phytoremediation. Ecotoxicol. 2004; 13: 637-646

20. Naumann B, Eberius M, Appenroth KJ. Growth rate based dose-response 
relationships and EC-values of ten heavy metals using the duckweed growth inhibition test (ISO 20079) with Lemna minor L. clone St., J Plant Physiol. 2007; 164:1656-64.

21. Zayed A, Gowthaman S, Terry N. Phytoaccumulation of Trace Elements by Wetland Plants: I. Duckweed. J Environ Qual. 1998; 27: 715-721.

22. Srivastava S, Mishra S, Tripathi RD, Dwivedi S, Trivedi PK, Tandon PK. Phytochelatins and Antioxidant Systems Respond Differentially during Arsenite and Arsenate Stress in Hydrilla verticillata (L.f.) Royle. Environ Sci Technol. 2007; 41: 2930-2936.

23. Srivastava $M, M a L Q$, Rathinasabapathi $B$, Srivastava $P$. Effects of selenium on arsenic uptake in arsenic hyperaccumulator Pteris vittata L. Bioresour Technol. 2009; 100: 1115-1121.

24. Shri $\mathrm{M}$ et al. Effect of arsenic on growth, oxidative stress, and antioxidant system in rice seedlings. Ecotoxicol Environ Saf. 2009; 72: 1102-1110.

25. Chakrabarty $D$ et al. Comparative transcriptome analysis of arsenate and arsenite stresses in rice seedlings. Chemosphere. 2009; 74: 688-702.

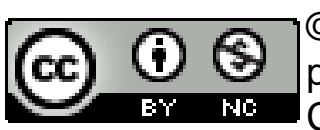

2018 by the authors. Submitted for possible open access publication under the terms and conditions of the Creative Commons Attribution (CC BY NC) license (https://creativecommons.org/licenses/by-nc/4.0/). 